tions - including the Public Record Office - had to be read in copy form in Ottawa. The product is testimony to hard work and is a commendation to the institution which has produced it.

This first detailed account of the origin, development and significance of RAF Ferry Command is highly recommended. It brings together a fascinating and relatively undiscovered topic; accurate, archival research; a tight, well-written text; a professional and very attractive presentation; and, all this, at an affordable price. Ocean Bridge is a must and will be thoroughly appreciated by aviation and military historians alike.

Major I.J.van der Waag, Documentation Service Directorate, Private Bag X289, Pretoria 0001.

\section{THE EVOLUTION OF MODERN LAND WARFARE; THEORY AND PRACTICE}

\section{Bellamy}

\author{
Routledge : 1990 \\ 314 bladsye \\ ISBN 0 - 415 - 02073 - 5 \\ prys onvermeld
}

\begin{abstract}
Christopher Bellamy is ' $n$ senior navorser verbonde aan die Sentrum vir Verdedigingstudies, Universiteit van Edinburgh. Sy akademiese opleiding sluit ' $n$ MA-graad in Oorlogstudies aan die King's College in Londen in. Afgesien hiervan was hy ook ' $n$ beroepsoldaat wat sy militêre skoling in die Koninklike Militêre Akademie te Sandhurst deurloop het. Hy het ook in die Britse Artillerie gedien. Bellamy is die skrywer van Red God of War : Soviet Artillery and Rocket Forces en The Future of Land Warfare.
\end{abstract}

The Evolution of Modern Land Warfare is gedurende die laaste jare van die Koue Oorlog tussen die VSA en die USSR geskryf. Die skrywer het van die veronderstelling uitgegaan dat die bestudering van Russiese en Oosterse krygsgeskiedenis dit vir NAVO-beplanners makliker sou maak om die aard van ' $n$ toekomstige oorlog teen die Warskou-verbondslande te begryp en daarvoor te kon voorberei. $\mathrm{Hy}$ beweer dat die literatuur oor die evolusie van moderne oorlogvoering te Eurosentries is en dat sy boek ' $n$ nuwe studieveld in dié verband open.

Die skrywer se doel is om ' $n$ opsomming te verskaf van die belangrikste militêre denke en konsepte oor landoorlogvoering soos dit sedert die 19de eeu ontwikkel het. Die konsepte wat hy as die belangrikste ag is :

a. Die ontstaan van die operasionele vlak van oorlogvoering. b. Die ontwikkeling van die lug-land geveg (Airland battle).

c. Die gebruik van mobiele magte wat voor die hoofmagte opereer.

d. Die geneigdheid van state in die moderne wêreld om weg te beweeg van grootskaalse oorlogvoering en die herlewing van die konsep van beperkte oorlogvoering soos deur Frederick die Grote gedurende die 18de eeu toegepas. Met ander woorde kort, hewige konvensionele konflikte. Verder ook die belangrike rol wat guerrilla-oorlogvoering in kontemporêre konflikte gespeel het.

Volgens hom is die beste manier om bogenoemde aan te spreek, die bestudering van die krygsgeskiedenis van die Russe in die 19 de en 20 ste eeue en Oosterse oorlogvoering sedert die Middeleeue.

Bellamy bespreek bogenoemde konsepte onder die volgende temas:

a. Basiese konsepte. Bellamy het ' $n$ aantal konsepte wat in moderne oorlogvoering gebruik word, benut om sy boek mee in te lui. Aspekte soos die beginsels van oorlogvoering, maneuvrering en uitputting, vuur en beweging, tipes maneuvreringsoperasies, operasies op eksterne en interne verbingingslyne en die rol van hindernisse in moderne landoorlogvoering word bespreek. Dit het hom tot die gevolgtrekking laat kom dat die sleutelelemente in moderne landoorlogvoering die volgende is :

i. Die impak van tegnologie op die slagveld.

ii. Militêre organisasies, hulle funksionering en die vermoë van state om hul in stand te hou en te bevoorraad. Hy noem dit die instansie se organisatoriese en logistieke vermoë.

iii. Die kuns van oorlogvoering en veral die ontstaan van die operasionele vlak van oorlogvoering weens die groter omvang van die gevegsone in oorlogvoering.

iv. C3I (Bevel, beheer, kommunikasie en inligting).

b. Die invloed van tegnologie op oorlogvoering. Die invloed van tegnologie is binne die raamwerk van die invloed wat dit op die ander sleutelelemente van oorlogvoering het, bespreek. Wat veral aandag geniet is die groter wordende doodmaak en trefafstandvermoë van wapens wat die omvang van die slagveld sodanig vergroot het dat tussen die taktiese en strategiese vlakke van oorlogvoering ' $n$ nuwe vlak, die operasionele vlak, ontstaan het. 
c. Die operasionele vlak van oorlogvoering. " $n$ Kort oorsig hieroor in die tydperk 1800 tot 1918 word verskaf.

d. Operasionele konsepte wat stagnasie in oorlogvoering, soos gedurende die Eerste Wêreldoor$\log , 1914-1918$, probeer verhoed. Hier gee Bellamy spesifiek aandag aan die sogenaamde Lugland geveg, die sogenaamde Operasionele Maneuvreringsgroep (OMG) soos ontwikkel in die Russiese en Sowjetleërs vanaf 1877-1945, die OMG in Asië, 1155-1418 en guerrilla-oorlogvoering in Asië, 1418-1975. Hierdie tydperke is met spesifieke verwysing na logistiek en state se ekonomiese vermoëns om militêre organisasies in stand te hou, bespreek. Verder is die werking van die operasionele vlak van oorlogvoering tydens hierdie veldtogte prakties geïllustreer, asook die rol van bevel, beheer, kommunikasie en inligting.

Bellamy gebruik sy bespreking om aan te toon dat die bestudering van krygsgeskiedenis verdedigingsbeplanners se taak vergemaklik.

Die skrywer gebruik ' $n$ interessante invalshoek om na sekere fasette van die evolusie van moderne landoorlogvoering te kyk. Om werklik reg te laat geskied aan so 'n omvattende onderwerp, verg egter meer as om net op Russiese en Oosterse oorlogvoering te fokus. Hy het ook nie werklik reg laat geskied aan die rol van bevel, beheer, kommunikasie en inligting in hierdie veldtogte nie. Dit word net terloops genoem. Weliswaar het hy hom ten doel gestel om ' $n$ inleidende studie oor die onderwerp te verskaf. Nogtans is te veel gefokus op sekere fasette van moderne landoorlogvoering wat die indruk kan skep dat dit al belangrike ontwikkeling was. In die proses word sekere fasette oorbeklemtoon terwyl belangrike ontwikkelinge in die evolusie van oorlogvoering onderskat word. In die bespreking van die Israeli's se operasie oor die Suez-kanaal in 1973 het hy 'n sterk argument gevoer om aan te toon dat die OMG werk en ' $n$ belangrike kenmerk van moderne landoorlogvoering is. Wat hy egter nalaat om te meld, is dat die OMG uit 'n gebalanseerde mag moet bestaan. Mobiele veggroepe beteken byvoorbeeld niks as daar nie ' $n$ sterk genoeg infanteriekomponent teenwoordig is om die pantser en artillerie te ondersteun nie. Hy kon ook in meer detail aangetoon het hoe ' $n$ gebrek aan behoorlike $C 3$ I ' $n$ OMG se operasie kan verongeluk.

Dit is ook te betwyfel of die onderwerpe wat hy gekies het voldoende antwoorde aan NAVO in 'n oorlog in Europa sou verskaf het. Nie almal sal saamstem dat ' $n$ Eurosentriese benadering nie hierin kan help nie. In Brittanje is in 1986 ' $n$ boek gepubliseer met die titel Old Battles and New Defences; Can we learn from Military History? Bekende Britse krygshistorici het hieraan meegewerk en hierdie boek verskaf net soveel bruikbare informasie oor ' $n$ moontlike oorlog in Europa teen die Warskouverdragslande soos dié van Bellamy.

Bellamy se boek het wel waarde in die sin dat dit die leser se aandag vestig op sekere belangrike ontwikkelinge in die evolusie van moderne landoorlogvoering. Die titel van die boek skep egter die indruk dat die boek al die belangrike fasette van die onderwerp aanspreek, wat beslis nie die geval is nie. Indien die subtitel eerder aangedui het dat belangrike lesse van konflikte waarin Russe en Oosterlinge betrokke was die kern van die bespreking vorm, sou dit minder gehinder het. Die keuse om oorlogvoering in Asië sover terug as Ghengis Khan te bespreek, is ook teenstrydig met die titel. In wese sukkel die skrywer om sintese te bereik deurdat daar te veel, te wyd bespreek word.

Ten spyte van bogenoemde kritiek lewer die boek tog ' $n$ belangrike bedrae tot beter begrip vir die aard van moderne landoorlogvoering. Die feit dat dit belangrike aspekte slegs terloops noem, bring egter mee dat die boek, soos wat die skrywer se doel was, slegs as inleidende studie oor die onderwerp gebruik kan word.

Lt kol C.J. Jacobs, Direktoraat Dokumentasiediens SANW, Privaatsak X289, Pretoria, 0001.

\section{DIE KAAPSE STAANDE MAG, 1872-1882}

\author{
J.S. Kotze \\ Staatsdrukker, Pretoria : 1993 \\ Opgeneem in die Argiefjaarboek vir \\ Suid-Afrikaanse Geskiedenis, jaargang 56. \\ 301 bladsye \\ ISBN 0797024867 \\ R20-00
}

Hierdie resensent is dankbaar dat hy oor iedere eksemplaar in die AJB reeks sedert 1938/1 beskik. Elke uitgawe, soms een soms twee per jaar, is ' $n$ winskoop wat prys, verskeidenheid en gehalte betref. Dit kan ook nie bra anders nie, want die bydraes in die tradisionele groen band is goedgekeurde Mverhandelinge en D-proefskrifte. Daarna is die inhoud weer eens nagegaan en kommentaar verwerk soos dit deur beoordelaars aangestip is toe opname in die AJB oorweeg is. In die lig van die lot van ander geslaagde reekse deur staatsbetrokkenheid, dink aan die Anglo-Boereoorlog en die Biografiese Woordeboek, kan ' $n$ mens maar net vertrou dat hierdie waardevolle reeks nie ook onthoof sal word nie.

Kotze se onderwerp, wat ' $n$ proefskrif vir die doktors- 